\title{
Considerações sobre o bairro e a vizinhança a partir do filme Smoke
}

\author{
Neighborhood issues discussed upon Paul Auster's movie Smoke
}

Maria Isabel Imbronito

Universidade São Judas Tadeu, São Paulo, SP, Brasil

\section{Resumo}

O presente artigo faz uma reflexão sobre o filme Smoke (Cortina de Fumaça), de 1995, de Paul Auster e Wayne Wang. A partir de uma obra de ficção, foi possível extrair elementos para uma leitura sobre a dinâmica urbana e as relações sociais que se estabelecem em torno de um comércio no Brooklyn, em Nova Iorque, Estados Unidos. Como fundamento para construção de uma interpretação de Smoke, utilizam-se, além de literatura sobre o filme e outros livros do autor, entrevistas de Auster nas quais o autor fornece os três argumentos para desenvolvimento deste texto. Os assuntos abordados são: o comparecimento da cidade de Nova Iorque, a ser apresentada com uma pesquisa sobre a morfologia do lugar; a importância das relações de vizinhança que se estabelecem ao redor do comerciante e as relações entre usuário e lugar; por fim, a construção do roteiro, assunto da maior importância, tendo em vista a envergadura do autor do filme, discutido a partir do entrelaçamento das estórias, da relação autor-personagem e da relação com a estória original, o "Conto de Natal de Auggie Wren", publicada no jornal The New York Times.

Palavras-chave: Arquitetura e cinema. Vizinhança. Paul Auster.

\section{Abstract}

This article discusses the movie Smoke (1995), by Paul Auster and Wayne Wang. Despite being a work of fiction, it was possible to extract elements to analyze urban dynamics and social relations established around a store in Brooklyn. The arguments used to discuss Smoke were found in the literature, other books from Auster, and also in interviews given by the author, in which he provides three arguments that were used for the development of this text. The listed subjects are: the city of New York, to be presented along with the research on its morphology; the importance of neighborhood relationships established around the dealer, and the relationship between user and place; and finally, the construction of the screenplay, subject of huge importance considering the author scale, discussed from the interweaving of the stories, the relationship between author and character, and the relationship with the original story, Auggie Wren's Christmas story, published in The New York Times.

Keywords: Architecture and cinema. Neighborhood. Paul Auster.

MII é arquiteta; Doutora em Arquitetura e Urbanismo, e-mail: imbronito@gmail.com 


\section{Introdução}

O presente ensaio tem como objeto o filme Smoke (Cortina de Fumaça), de 1995, escrito por Paul Auster e dirigido por Auster e por Wayne Wang. 0 roteiro surgiu após Wang propor transformar em filme o "Conto de Natal de Auggie Wren", de Auster, estória publicada no jornal The New York Times, em 1990.

No filme, o "Conto de Natal de Auggie Wren" aparece em destaque, uma vez que as passagens relacionadas à estória de Natal e às fotos de Auggie Wren assumem o tratamento em preto e branco, assim como um ritmo diferente do resto do filme. Além de abordar, de maneira extraordinária, o pequeno texto literário original, o roteiro incorporou outras estórias inéditas escritas por Auster especialmente para o filme. As cinco partes que compõem o filme estão associadas às personagens: Paul Benjamin (William Hurt), Rashid (Harold Perrineau Jr.), Ruby (Stockard Channing), Cyrus (Forest Whitaker) e Auggie (Harvey Keitel). Apesar dessa divisão em cinco partes, as estórias se comunicam e se inter-relacionam, tendo, em cada uma delas, a participação das demais personagens. Paul Benjamin, escritor, e Auggie, comerciante de cigarros, são amigos; Rashid, em fuga e em busca do pai (Cyrus), estabelece vínculo com Paul Benjamin; Ruby, em busca da filha, pede auxílio ao antigo namorado, Auggie.

0 tipo de leitura que se pretende do filme de Auster e Wang não objetiva uma reflexão literária ou propriamente cinematográfica. Assunto de um debate promovido na Semana de Arquitetura da Universidade São Judas Tadeu ${ }^{1}$, o filme serviu como base para a discussão de questões relacionadas à cidade e à vida urbana. Auster, em entrevistas concedidas à BFI Film Forever (2013) e à Annette Insdorf (Auster, [1995]), fornece os três argumentos que foram utilizados para a discussão do filme. 0 primeiro deles é que a encomenda do New York Times para o "Conto de Natal de Auggie Wren" foi clara quanto a estabelecer tema e lugar. A estória, publicada na noite de Natal em 1990, deveria se passar em Nova York. A prerrogativa de referir à cidade fica evidente no conto e no filme, por isso a primeira abordagem deste texto é o modo como a cidade de Nova Iorque é mostrada.

\footnotetext{
${ }^{1} \mathrm{O}$ filme foi objeto de aula e debate na Semana de Arquitetura, no curso de Arquitetura e Urbanismo da Universidade São Judas Tadeu, em 4 de setembro de 2015, como atividade do Grupo de Pesquisa da Pós-Graduação, inserido no projeto Arquitetura e Cinema.
}

No filme, o espaço urbano presente nas cenas vem acompanhado de comentários perspicazes e de enquadramentos cuidadosos, abertos e fechados, os quais informam sobre a localização, a característica dos espaços e seu uso. 0 bairro evidenciado é o Brooklyn, local de moradia de Auster. A vivência cotidiana do autor na vizinhança e a sua percepção bem informada são transpostas às falas das personagens, à dinâmica das cenas externas e aos passantes que povoam essas cenas. Ao mesmo tempo, o filme penetra nos espaços habitados e revela, além do modo de morar, como se dá a relação "dentro-fora", entre o espaço de permanência e o espaço da cidade. 0 roteiro fornecido por Auster é bastante preciso na descrição dos ambientes internos e externos. Auster cita, em entrevistas à BFI e à Insdorf (Auster, [1995], p. 12) que, durante a vinda de Wang a Nova Iorque para tratarem do filme, a primeira providência foi visitar os lugares onde se passaria a estória, de modo que a relação desta com o lugar ficou preservada e amplificou-se no filme, sob o olhar de Wang.

O segundo ponto em evidência a ser discutido no texto são as relações humanas que ocorrem na condição de vizinhança, com foco em torno do comerciante. Na mesma entrevista à BFI, Auster diz que, estando sem ideias para escrever o conto de Natal, observou seu pacote de cigarrilhas holandesas e se lembrou do comerciante que as vendeu (o mesmo argumento aparece escrito no "Conto de Natal de Auggie Wren"). Auster é claro ao afirmar que tinha uma relação frequente com o comerciante, mas este não pertencia ao seu círculo íntimo de amizades. Revela que o conhecia há muitos anos e que sempre mantinham boas conversas. Auster conclui que justamente o contato com diferentes pessoas na cidade é que tornava a vida em Nova Iorque interessante. Essa percepção do contato humano na metrópole transforma-se no principal argumento de sua estória de Natal, e o autor estende esse motivo para as demais estórias que aparecem no roteiro do filme. A perspicácia de Auster sobre o papel do comerciante é pretexto para desenvolvermos uma análise sobre a vida social no bairro. 0 filme "reproduz" a ambiência e a rede de relações sociais e de uso do espaço que são propícios para ilustrar discussões sobre a vizinhança, fundamentadas por referências teóricas como Jane Jacobs, Michel de Certeau e Xavier Monteys. Então, o segundo objetivo deste texto é investigar, relacionar e refletir sobre a fundamentação teórica em torno das relações sociais no espaço do bairro. 
O terceiro argumento colocado por Auster, e utilizado para reflexão neste texto, refere-se ao processo criativo do texto e do filme. Na mesma entrevista à $B F I$, Auster diz que fez o roteiro para Wang, ou seja, "moldou" seu texto ao pressupor o modo de filmar de Wang. Essa informação, aliada ao surgimento da estória de Natal (uma narrativa de Auggie para Paul Auster, transcrita pelo autor que, presente no filme, recebe o nome de Paul Benjamin) e ao modo como as cinco estórias do filme se relacionam, é material para abordar a relação autor-personagem e a diluição da autoria promovida por Auster, estabelecida a partir do dialogismo de Bakhtin.

\section{O espaço da vizinhança}

Smoke faz o entrelaçamento da estória de cinco personagens, amarradas pela casualidade, em torno de uma tabacaria que ocupa uma esquina movimentada no miolo do Brooklyn. Registra-se, em tomadas externas, um tecido urbano consolidado e dinâmico: a morfologia apreendida na escala do usuário, o uso diversificado do solo, o movimento intenso das ruas e calçadas. Nas tomadas internas, informa-se sobre a habitação e o comércio local. É reproduzida, por assim dizer, a apropriação do espaço habitável, considerado de modo estendido como o espaço privado, o espaço privado de uso público e o espaço público, ou seja, o apartamento, a tabacaria, e a rua e o bairro, respectivamente.

Existem duas localizações diferentes para a tabacaria. A primeira a ser analisada é fornecida no filme: esquina da $3^{\mathrm{dr}}$ Street com a $7^{\text {th }}$ Avenue, endereço que nos leva a Park Slope, Brooklyn. A segunda que iremos abordar, Court Street, é indicada no "Conto de Natal de Auggie Wren" (Auster, 2009).

\section{O tecido urbano em Park Slope, Brooklyn}

Uma leitura da cidade em torno da localização da tabacaria indicada no filme revela um tecido de interesse histórico, caracterizado por edifícios do final do século XIX e início do século XX, implantados em uma malha retangular regular que determina quadras estreitas e compridas. 0 traçado viário divide-se, perpendicularmente, em ruas e avenidas que apresentam regras claras de ocupação (Figuras 1, 2, 3).

As ruas são delimitadas pelas faces extensas das quadras e têm uso residencial. 0 parcelamento adota lotes com testada estreita, ocupados por prédios de habitação coletiva de três a cinco pavimentos formando renques contínuos que determinam uma volumetria constante, porém de aparência variada, uma vez que é composta por edifícios independentes. As construções

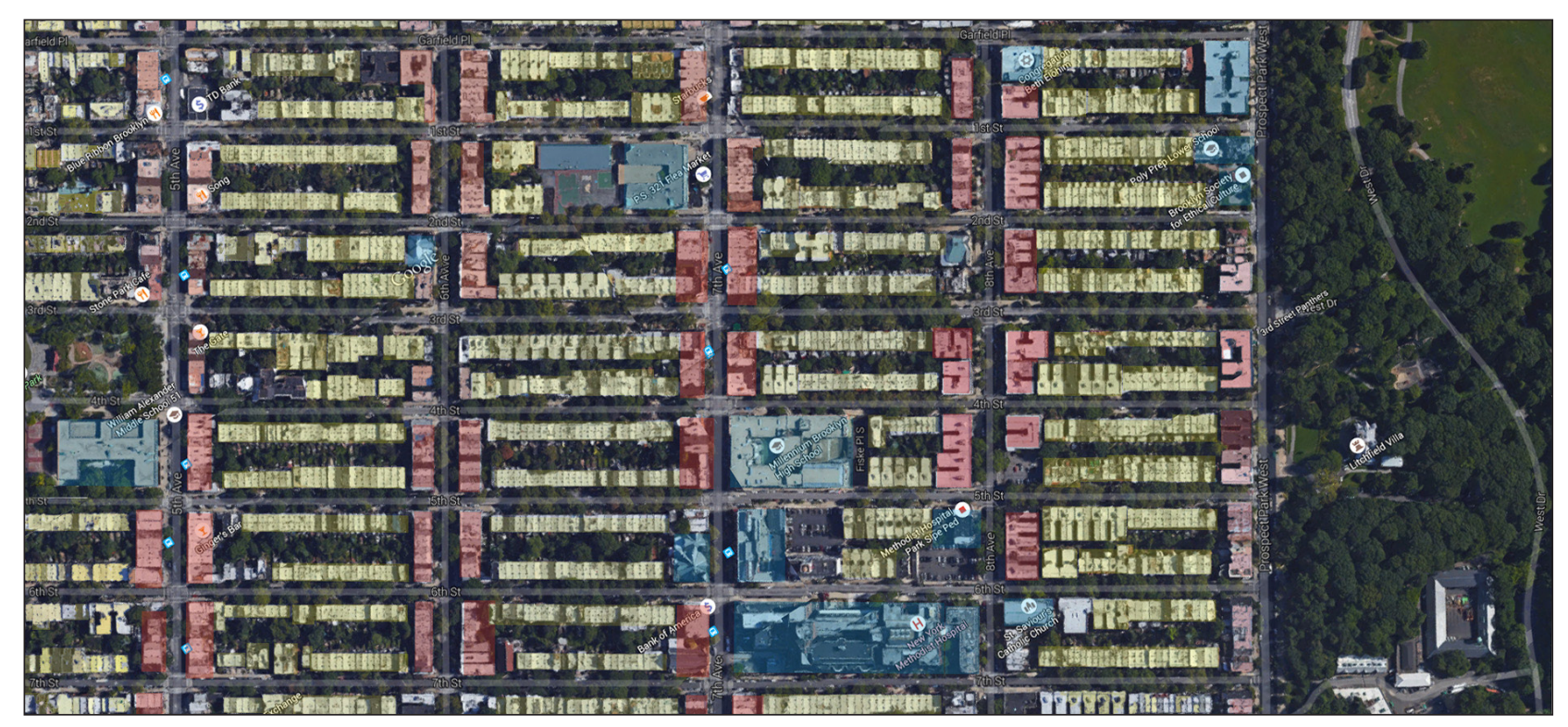

Figura 1 - Tecido urbano em Park Slope, Brooklyn. Uso do solo esquematicamente indicado nas cores amarelo (residencial, nas ruas), larania (misto, nas avenidas) e azul (institucional, nas avenidas). À direita, nota-se o Prospect Park Fonte: Fotos originais do Google (2015) tratadas pela autora. 


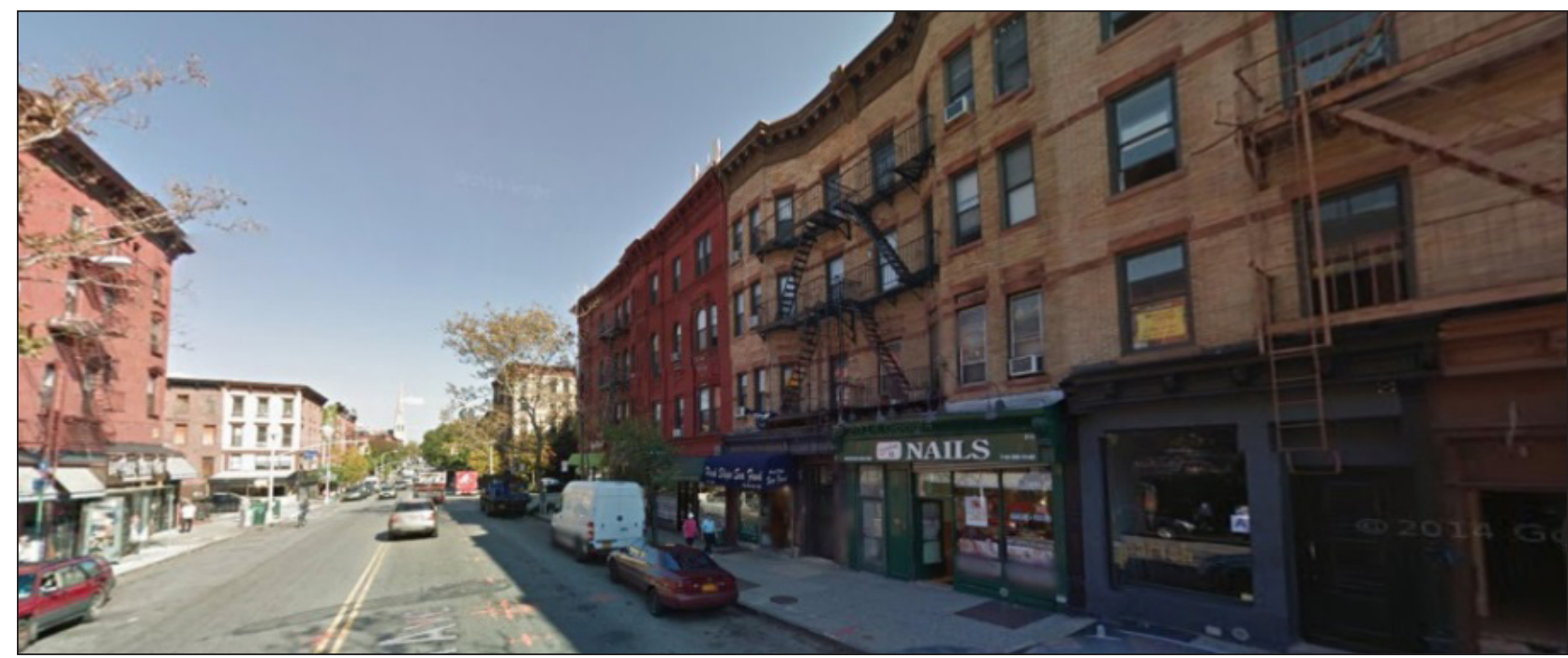

Figura 2 - $7^{\text {th }}$ Avenue, Park Slope, Brooklyn, com o uso comercial no térreo Fonte: Google (2015).

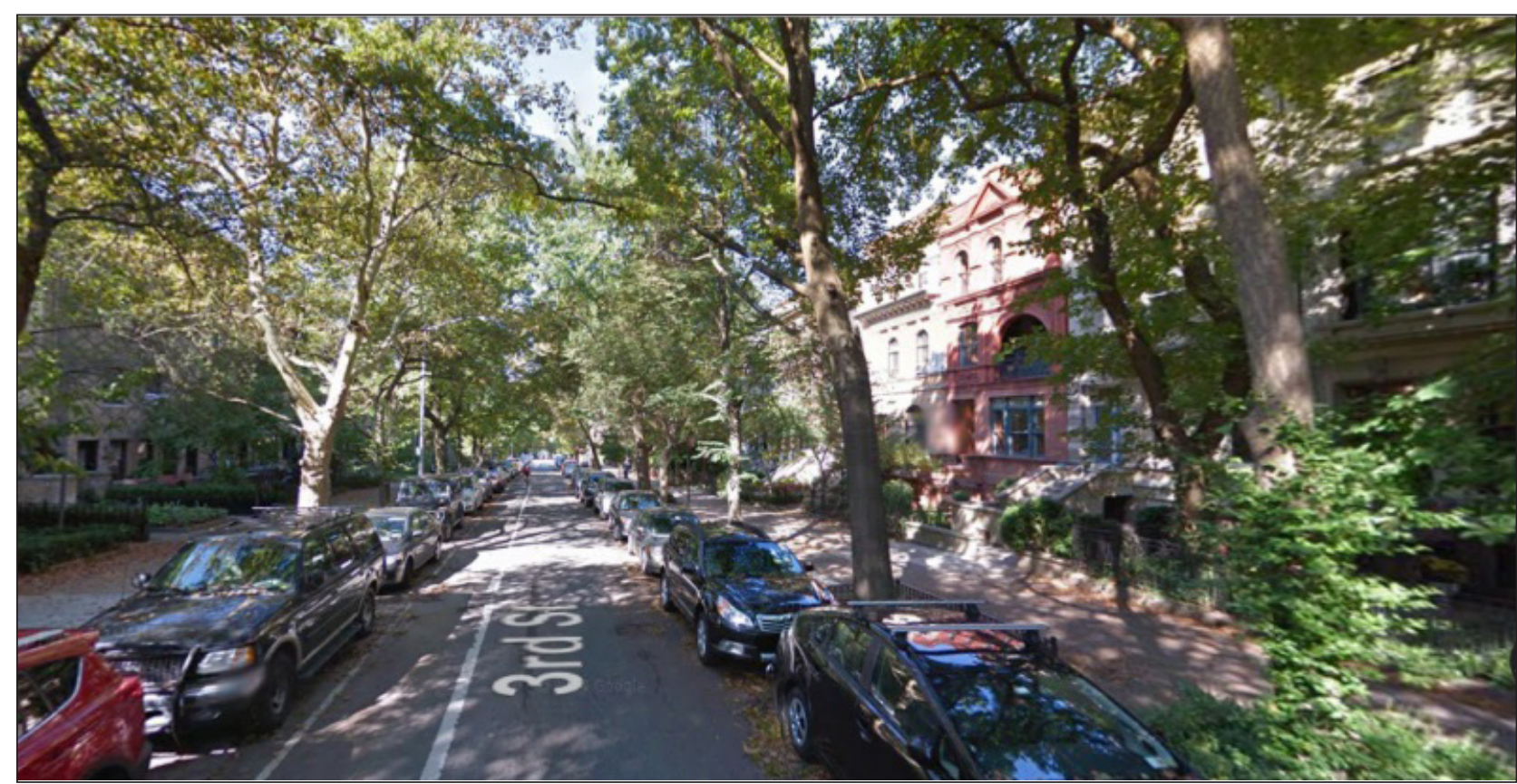

Figura 3 - Vizinhança residencial, $3^{\text {dr }}$ Street, Park Slope, Brooklyn Fonte: Google (2015).

têm originalmente caráter estereotômico, e as fiadas de pedra vermelha à vista dão nome ao tipo de ocupação - brownstone neighborhoods, que remete à morfologia e, de modo indissociável, à tipologia dos apartamentos.

Com frente para as menores faces das quadras, paralelas à Avenida Prospect Park West, as avenidas apresentam uso misto com comércio no térreo e serviços ou habitações nos andares superiores. Apesar da alteração de uso, os edifícios das avenidas têm volumetria compatível com a dos prédios de habitação dispostos nas ruas e arrematam formalmente a quadra, mantendo o gabarito.

Esse tipo de quadra alongada apresenta exatamente a proporção que Jane Jacobs critica quando defende sua proposta de quadra curta, acrescentando ruas no meio da quadra residencial e desmontando a organização principal desse modelo de tecido urbano. Tendo 
escrito seu livro "Morte e Vida nas Grandes Cidades" em 1961, diante de um momento de grande violência na cidade de Nova Iorque, a jornalista, por meio de explicações e croquis, considera a quadra alongada e a separação de usos inconveniente para promover a vitalidade nas calçadas. Segundo os argumentos de Jacobs, edifícios com uso, tipo e idades diferentes devem se misturar, com a necessidade de um número maior de ruas para promover possibilidades de percurso diferentes (Jacobs, 2003, p. 197).

Atualmente, o Park Slope constitui um ambiente urbano qualificado. Em vez de creditar a vitalidade urbana unicamente aos aspectos privilegiados por Jacobs em seu livro, pode-se perceber que parte do sucesso de Park Slope relaciona-se à sua estrutura física, que mantém características originais do tecido do século XIX. Além da ocupação antiga, localização privilegiada e presença de uso diversificado em meio a áreas de habitação bastante protegidas, é possível concluir que a vitalidade no bairro histórico deve-se ao acerto na proporção entre habitação e comércio presente nesse tecido, que é resultado tanto da morfologia (malha, traçado, quadra) como das regras claras de ocupação e uso do solo. A malha retangular propicia maiores extensões de ruas do que de avenidas, o que define mais frente e área para as habitações, dispostas ao longo das ruas. Isso garante uma densidade populacional conveniente, apesar do baixo gabarito, para manutenção e vitalidade dos comércios, dispostos principalmente na $5^{\text {th }}$ Avenue e na $7^{\text {th }}$ Avenue. Como as avenidas com comércio surgem em intervalos maiores, existe efetivamente no bairro menos comércio do que habitação, o que evita imóveis comerciais subutilizados ou vazios. As avenidas são constantemente cortadas pelas ruas e, portanto, frequentemente alimentadas com usuários moradores do bairro.

Além disso, as avenidas são vias de passagem que conectam o bairro a outros distritos. Em maior escala, analisadas sob o ponto de vista dos fluxos urbanos, as avenidas cumprem o papel principal, uma vez que a continuidade do traçado das ruas residenciais é interrompida pelo Prospect Park, dando-lhes caráter local. A exceção fica a cargo da $9^{\text {th }}$ Street e da $15^{\text {th }}$ Street, que são ruas estruturais mais largas e apresentam comércio. Desse modo, a implantação geral do bairro e sua relação com a cidade reforça o desenho do traçado na separação de usos entre ruas e avenidas, tornando possível contrapor ao fluxo e ao movimento do comércio das avenidas a tranquilidade própria das ruas residenciais. Ao contrário da mistura de usos que propõe Jacobs, a concentração do comércio nas avenidas e as longas, mas agradáveis, ruas locais vieram a se tornar uma grande qualidade em Park Slope.

Nota-se que as ruas possuem largas calçadas arborizadas e jardins frontais, o que contribui para a qualidade ambiental próximo às habitações, enquanto que as avenidas têm aumento significativo do leito carroçável e vias de mão dupla, além de calçadas estreitas sem recuo frontal, o que contribui para a visibilidade dos comércios.

\section{O tecido urbano em Brooklyn Heights}

A região da cidade onde se localiza a tabacaria pelo texto original de Auster publicado no New York Times (Auster, 2009) apresenta estrutura urbana e distribuição do uso do solo menos rígidas do que o Park Slope (Figuras 4, 5, 6).

O Brooklyn Heights é um dos bairros citados por Jacobs como exemplo de densidade urbana adequada à boa vitalidade das calçadas. Além da alta densidade, tem como característica a mistura de usos, tipos, idades e gabaritos dos edifícios, fatores incentivados por Jacobs (2003) em "Morte e Vida das Grandes Cidades". Entretanto, é possível perceber, por trás da variação aparente, uma organização muito similar ao Park Slope no traçado, proporção da quadra e até na setorização de usos, apesar dessa organização ser menos estrita do que no distrito histórico.

Sobre o traçado e conformação das quadras, nota-se a adequação da malha de proporção retangular às principais vias estruturadoras do tecido e às suas direções predominantes, o que resulta em um desenho irregular das quadras. A orientação principal identificada para as quadras retangulares sofre uma inversão a partir da Rua Clinton. De modo geral, apesar de o bairro conter mais uso misto, é possível notar o uso estritamente residencial nas travessas entre a Court Street e a Clinton Street, bem como nas ruas perpendiculares compreendidas entre a State Street e Joralemon Street. A aparência dessa vizinhança residencial é muito similar àquela encontrada no Park Slope. 0 comércio, por sua vez, está concentrado na Atlantic Avenue e na Court Street. 


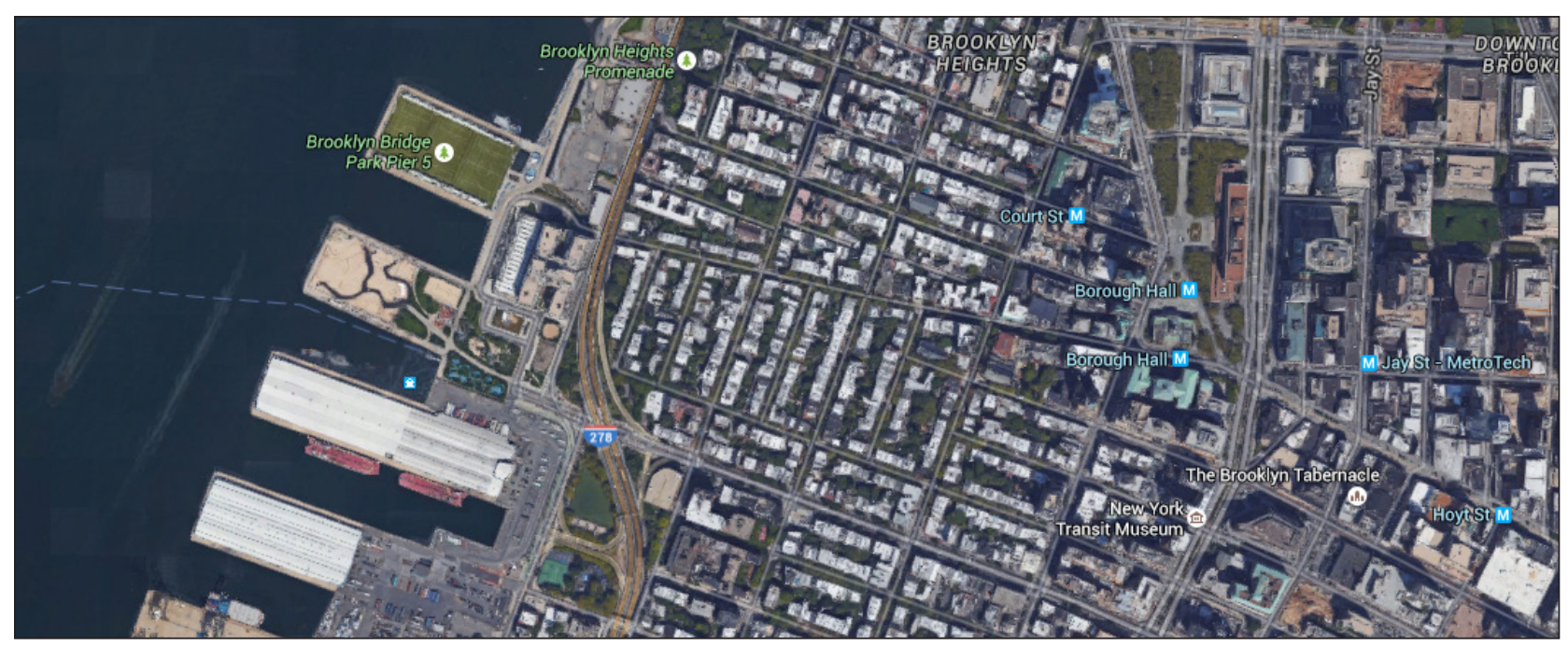

Figura 4 - Tecido urbano no Brooklyn Heights, com a forma inconstante das quadras, submetidas às direções predominantes das principais vias Fonte: Google (2015).

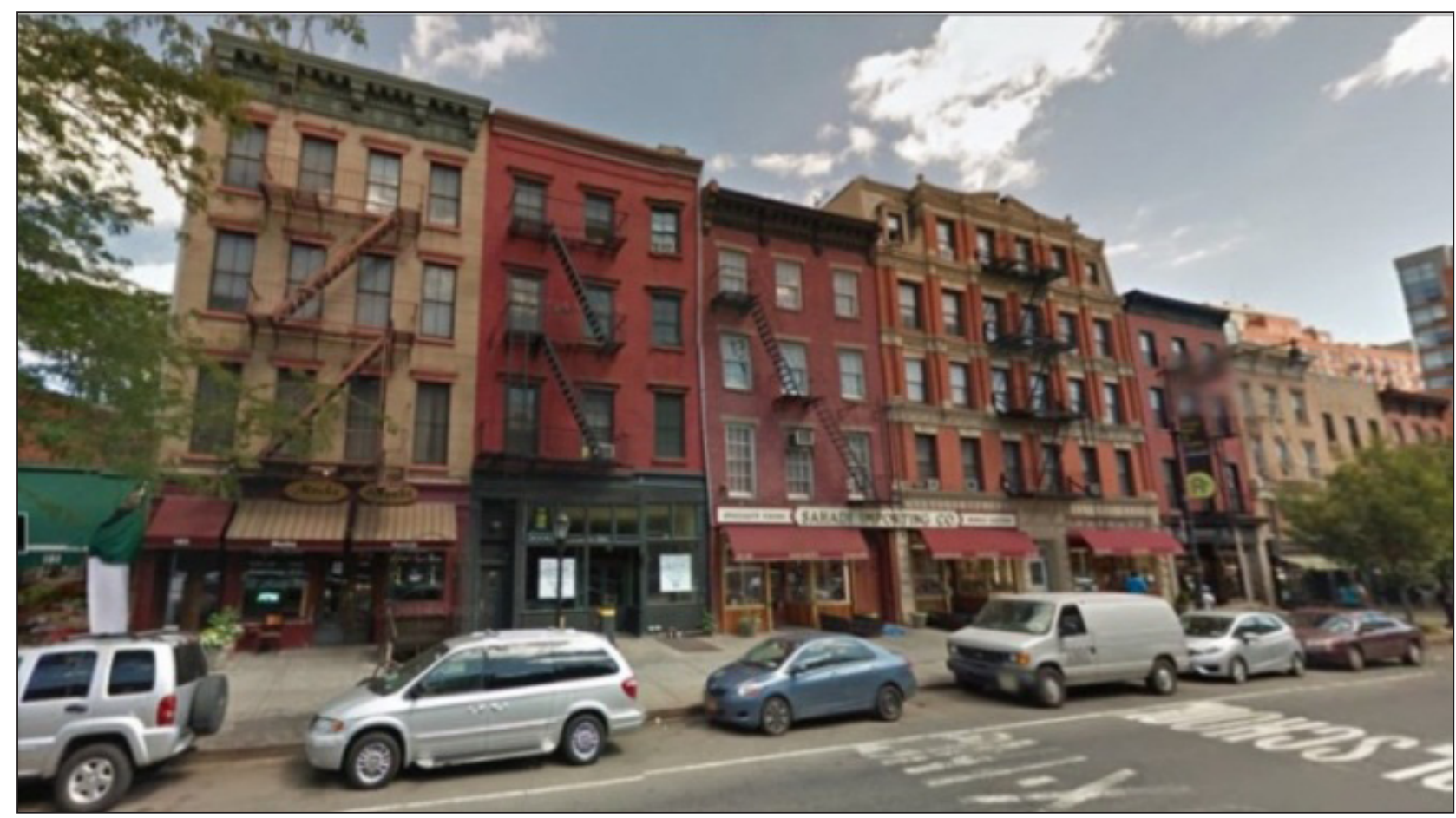

Figura 5 - Uso misto com comércio na Atlantic Avenue, Brooklyn Heights Fonte: Google (2015).

\section{A tabacaria e o comerciante}

A ausência de padarias e de bancas de jornal, locais onde, por aqui, compra-se cigarro, institui a presença das tabacarias norte-americanas como estabelecimentos comerciais de rua. Nas cenas iniciais, dentro da tabacaria, Auggie Wren fala e os frequentadores escutam ${ }^{2}$. Ali são apresentados, ao mesmo tempo, o espaço e dinâmica das relações sociais do lugar.

Na tabacaria onde Auggie trabalha, além da exibição dos produtos (cigarros, charutos, acessórios e revistas),

${ }^{2}$ Auggie Wren conta ao funcionário e aos cambistas que estão na tabacaria fatos sobre a vida de Paul Benjamin. 


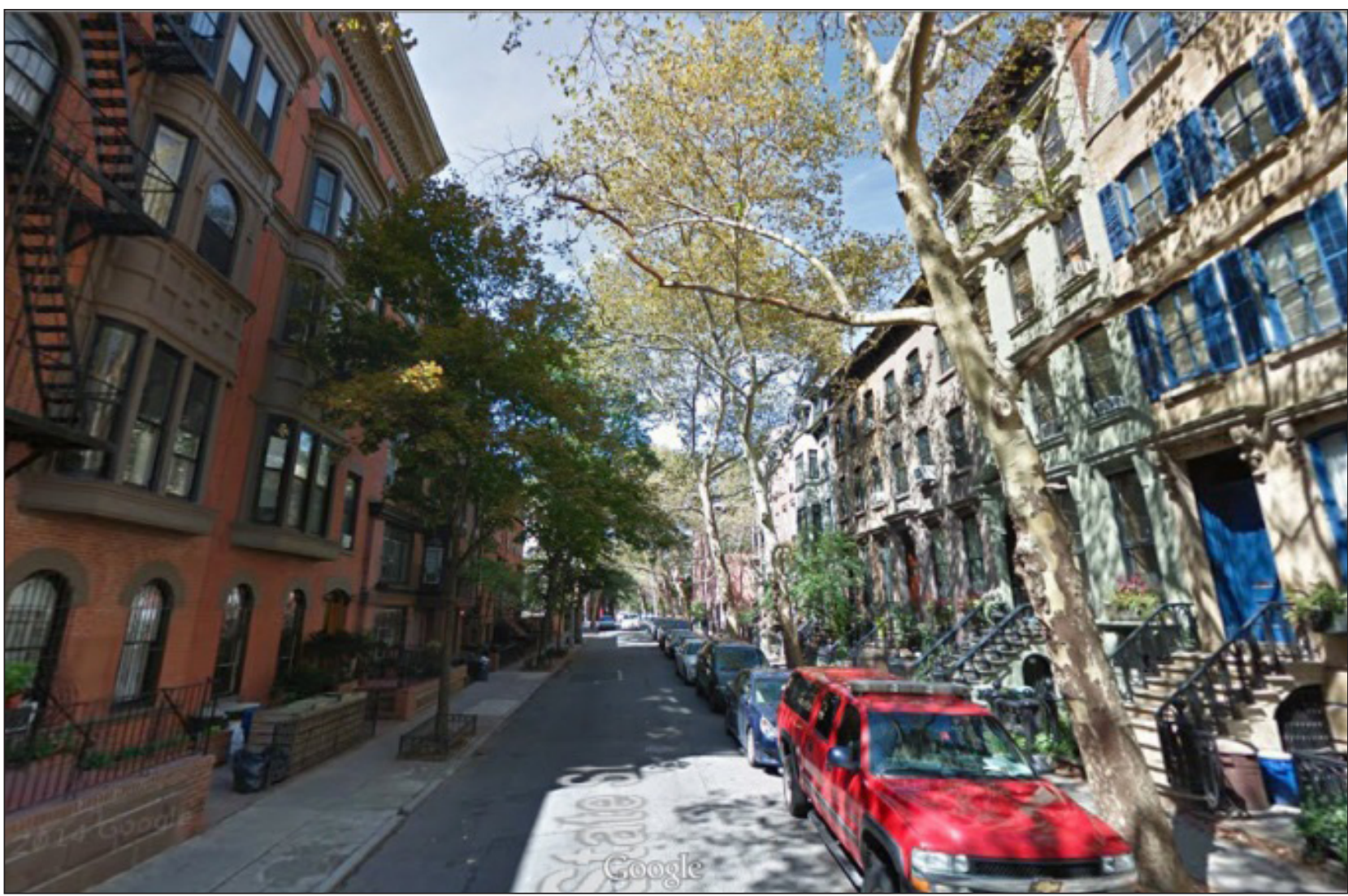

Figura 6 - Rua residencial, State Street, Brooklyn Heights

Fonte: Google (2015).

é possível notar objetos que caracterizam o ambiente e seu dono. Trata-se de uma representação do universo masculino que evoca o tempo do ócio, do cigarro, da leitura de jornal e da conversa à toa. 0 índio americano, mascador de tabaco, aparece em escala real próximo à entrada. 0 beisebol está presente nas fotos espalhadas e na televisão ligada. As paredes são uma colagem de informações nos breves espaços entre as janelas; estas, por sua vez, são, sem dúvida, o grande atrativo devido ao movimento da avenida. Por localizar-se na esquina, as janelas envidraçadas expandem o espaço da loja para a calçada, e, assim, é possível ver carros e pessoas passando ininterruptamente (Figura 7).

0 consumidor de cigarro é constante e estabelece uma relação cotidiana com o comerciante e com a tabacaria. Fumar é um hábito: compra-se cigarro todo dia. Desse modo, o espaço da compra rápida se transforma também em lugar de permanência, onde é possível conversar sobre esportes, negócios e vizinhança. A loja torna-se um espaço habitável, porque é apropriável por usuários cotidianamente presentes. Um local familiar onde as pessoas se reconhecem e se sociabilizam, onde as relações humanas podem se desenvolver.

\section{O movimento da tabacaria e o papel da figura pública}

No filme, o interior da tabacaria é introduzido no meio de uma cena cotidiana. 0 desenrolar da cena não é mostrado desde o início: o filme começa interrompido, com uma conversa em andamento.

A permanência faz Auggie Wren, comerciante da tabacaria, experimentar uma continuidade temporal diferente daquela vivida pelo usuário que entra, efetua uma compra e sai. Para o comerciante, a entrada de um freguês inserida no meio do dia não é o início da ação, mas apenas parte de um eterno desenrolar de eventos sobrepostos. Essa mesma impressão é partilhada por outros "habitantes" da tabacaria: funcionários e cambistas que prolongam sua estada para além do tempo da compra. 


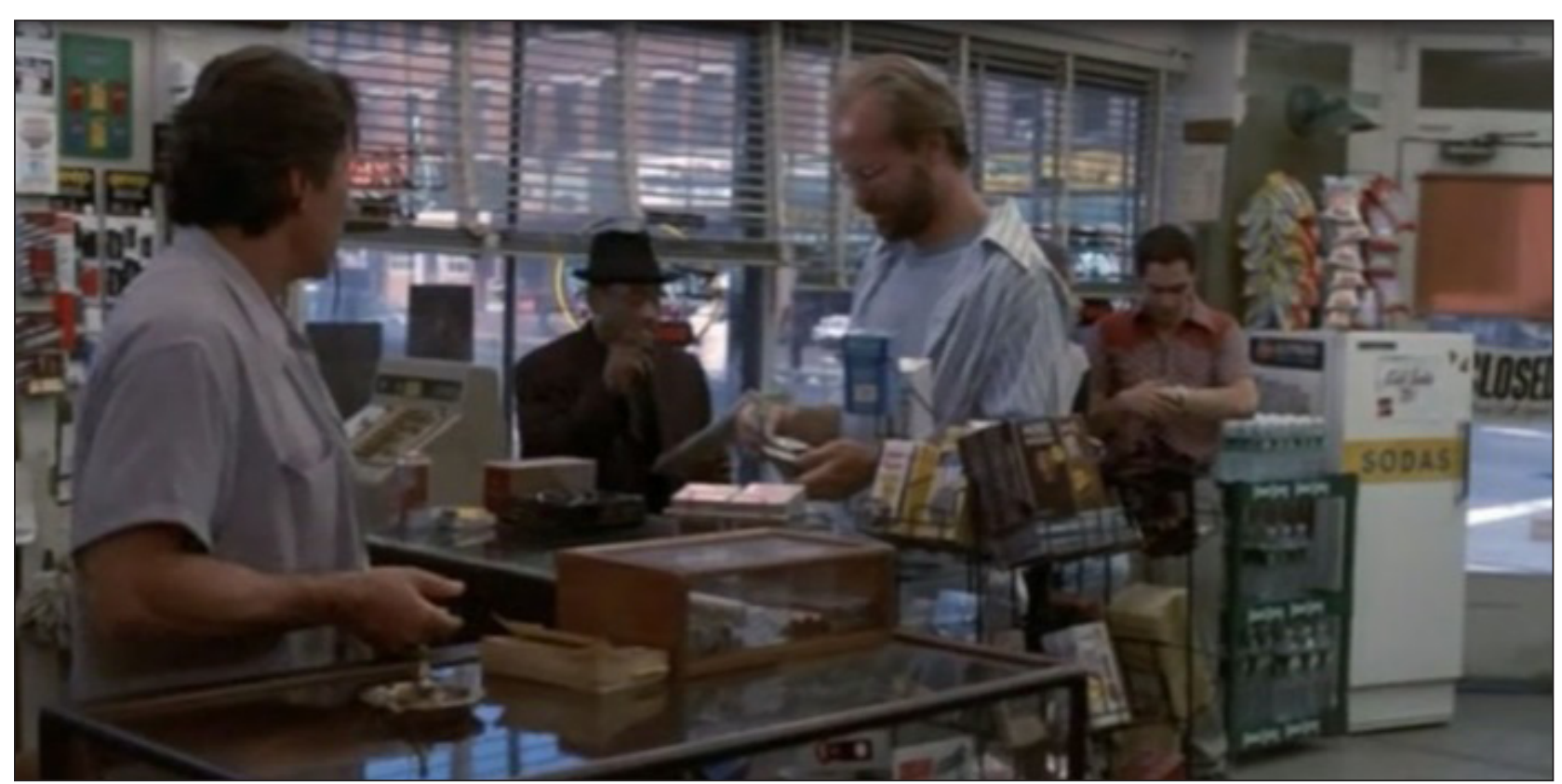

Figura 7 - Interior da tabacaria, com Paul Benjamin comprando cigarros e a janela se abrindo para o movimento da rua Fonte: Extraído do filme Smoke (Wang et al., 1995). Cortesia de MIRAMAX, LLC.

Em seu "Conto de Natal de Auggie Wren", Paul Auster relata como evolui sua relação com "Auggie" ${ }^{3}$. Para o autor, o vendedor é, inicialmente, aquela figura estranha "que sempre tem alguma coisa engraçada a dizer sobre o tempo, sobre beisebol ou sobre os políticos em Washington" (Auster, 2009, p. 8). Até que Auggie localiza em Auster o escritor, e passam a compartilhar ideias artísticas, pois "Auggie se considerava um artista”. A relação entre ambos passa então a se aprofundar.

É possível traçar paralelos entre a atuação de Auggie e o estudo feito pelo pesquisador Pierre Mayol (Certeau et al., 2000, p. 117) no bairro de Croix Rousse ${ }^{4}$, em Lion, na França, onde o pesquisador descreve o cotidiano de Robert, um comerciante da Rue de Rivet. Dono de um armazém estabelecido há tempos no bairro, Robert conhece a maioria dos fregueses: invoca seus nomes e de familiares próximos, conhece suas preferências e é capaz de conferir a relações efetivamente públicas certas particularidades. Conforme

\footnotetext{
${ }^{3}$ Auggie Wren é apresentado como uma figura existente, cujo nome foi trocado para compor a personagem do conto. Em entrevista à BFI, Auster confirma a existência do vendedor de cigarros que inspirou a estória.

${ }^{4}$ A primeira parte do livro de Michel de Certeau, intitulada Morar, é de autoria de Pierre Mayol, conforme sumário e introdução do livro.
}

Mayol, os assuntos giram em torno das atualidades, dos produtos a serem vendidos, sua origem etc. Além disso, Robert transmite as notícias sobre a comunidade. Devido à sua posição, estabelecida ao longo do tempo e ao contato com grande número de pessoas, as notícias locais assumem por meio dele um tom "oficial".

Jacobs (2003), em "Morte e Vida das Grandes Cidades", retrata situações parecidas na vizinhança de Greenwich Village, Nova Iorque. Segundo a autora:

[...] a estrutura social da vida nas calçadas depende em parte do que pode ser chamado de uma figura pública autonomeada. A figura pública é aquela que tem contato frequente com um amplo círculo de pessoas e interesse em tornar-se uma figura pública. Ela não precisa ter nenhum talento ou conhecimento especial para desempenhar sua função, embora quase sempre os tenha. Precisa apenas estar presente [...]. Sua principal qualificação é ser pública, conversar com várias pessoas diferentes. É assim que se transmitem as notícias que são do interesse das ruas. [...]. A maioria das personagens de rua está estabelecida em locais públicos. São pessoas que cuidam de lojas ou de bares ou coisa parecida. (Jacobs, 2003, p. 73) 
Jacobs (2003, p. 65) descreve a rotina de um comerciante dono de uma doceria em Greenwich Village, que extrapola sua função de vendedor e presta todo o tipo de assistência: atravessar a rua com crianças, emprestar guarda-chuva, guardar a chave de um cliente, guardar pacotes, passar sermão em adolescentes que foram comprar cigarros, fornecer indicação de ruas, informar preços de aluguéis, ouvir histórias pessoais, aconselhar pessoas, entre outras.

Os dois autores citados (Jacobs e Mayol) enfatizam que, apesar da constância das relações em torno da figura do comerciante, a intimidade deve ser relativamente preservada a fim de resguardar a privacidade da convivência pública. 0 comerciante deve ser capaz, portanto, de manter claro o limite entre o mundo público e o privado, sem se intrometer ou levar adiante os assuntos pertencentes a cada um. Conforme Jacobs (2003, p. 63), a privacidade relaciona-se à possibilidade de escolha em revelar nosso mundo particular a estranhos. A relação estendida após o horário comercial é privilégio de poucos escolhidos. Transposto para o filme de Auster, isso significaria que, apesar de Auggie compartilhar afinidades e cigarros com frequentadores e clientes, as relações que se ampliam para fora do espaço da tabacaria, onde se compartilham momentos e estórias, são de amizade identificadas como tal, o que terminará ocorrendo entre Auggie e Paul.

Em Smoke, Auggie, o comerciante da tabacaria, tem conhecimento sobre fatos e pessoas, além de dominar informações. É possível compreender melhor o papel de Auggie ao arranjar um emprego para Rashid (a pedido de Paul Benjamin), ao emprestar dinheiro e fazer negócios, ao dar conselhos e opiniões ou ao contar estórias.

Além de informar sobre as notícias do bairro e de sua fala assumir o tal "tom oficial", Auster explora o fato de que Auggie desempenha o papel de guardião da memória, o que é demonstrado nas cenas iniciais, nas quais comenta com fregueses sobre o passado de Paul e o assalto que matou sua mulher. Ao mesmo tempo que guarda a memória, Auggie a registra por meio de seu hobby: fotografar a tabacaria a partir da esquina oposta, todos os dias no início da manhã. Além de dominar os fatos a partir da tabacaria (seu ponto fixo) e de observar a cidade através das janelas, Auggie desenvolve um olhar de fora, ao ver a tabacaria a partir da rua. Auster revela que, para
Auggie, o registro fotográfico situa sua tabacaria como um lugar no mundo.

\section{O registro cotidiano da tabacaria e a vida na calçada}

Auggie usa uma câmera fotográfica cuja origem faz parte da imbricada trama de estórias do filme e que o leva ao projeto de fotografar a tabacaria a partir da esquina oposta, todos os dias, no início da manhã ${ }^{5}$.

Ao mostrar para Paul a ampliação das 4 mil fotos tiradas de um mesmo lugar, Auggie precisa reforçar retoricamente o que deve ser visto, ou aquilo que ele próprio descobriu em sua tarefa cotidiana: colocar a atenção na passagem do tempo e, principalmente, na sucessão cotidiana dos eventos e pessoas da calçada. Auggie sugere que a qualidade das fotos está em perceber as transformações que ocorrem em um mesmo lugar. Por isso Auggie recomenda o olhar vagaroso: o ato de vagar o olhar pelas fotos, lentamente, em busca de variações daquilo que não se repete.

Sua fala instiga a buscar diferenças de luz, a chuva e o sol, o verão e o inverno, o dia de semana e o fim de semana. Somadas a essa geovariação, as fotos exibem, principalmente, as pessoas que habitam aquele lugar e fazem o registro de sua presença. A fala de Auggie vai, então, descortinar esse movimento humano: às vezes aparecem as mesmas pessoas, outras vezes elas são diferentes. Algumas pessoas diferentes se tornam familiares. Outras frequentam a rua por algum período e depois desaparecem.

Surge, em câmera lenta, a sequência de momentos capturados por Auggie: ao serem admiradas por Paul, tomam a tela e se apresentam ao olhar de quem assiste ao filme e, assim, assumimos o lugar de Paul Benjamin. Em fragmentos congelados (Figura 8), mostra-se aquilo que Jane Jacobs chamou de balé da calçada:

Sob a aparente desordem da cidade tradicional, existe, nos lugares em que ela funciona a contento, uma ordem surpreendente que garante a manutenção da segurança e a liberdade. É uma ordem complexa. Sua essência é a complexidade do uso das calçadas, que

\footnotetext{
${ }^{5}$ No conto original de Paul Auster, Auggie Wren faz as fotografias no cruzamento da Atlantic Avenue com a Clinton Street, ou seja, uma esquina próxima à Court Street, endereço fornecido da tabacaria.
} 

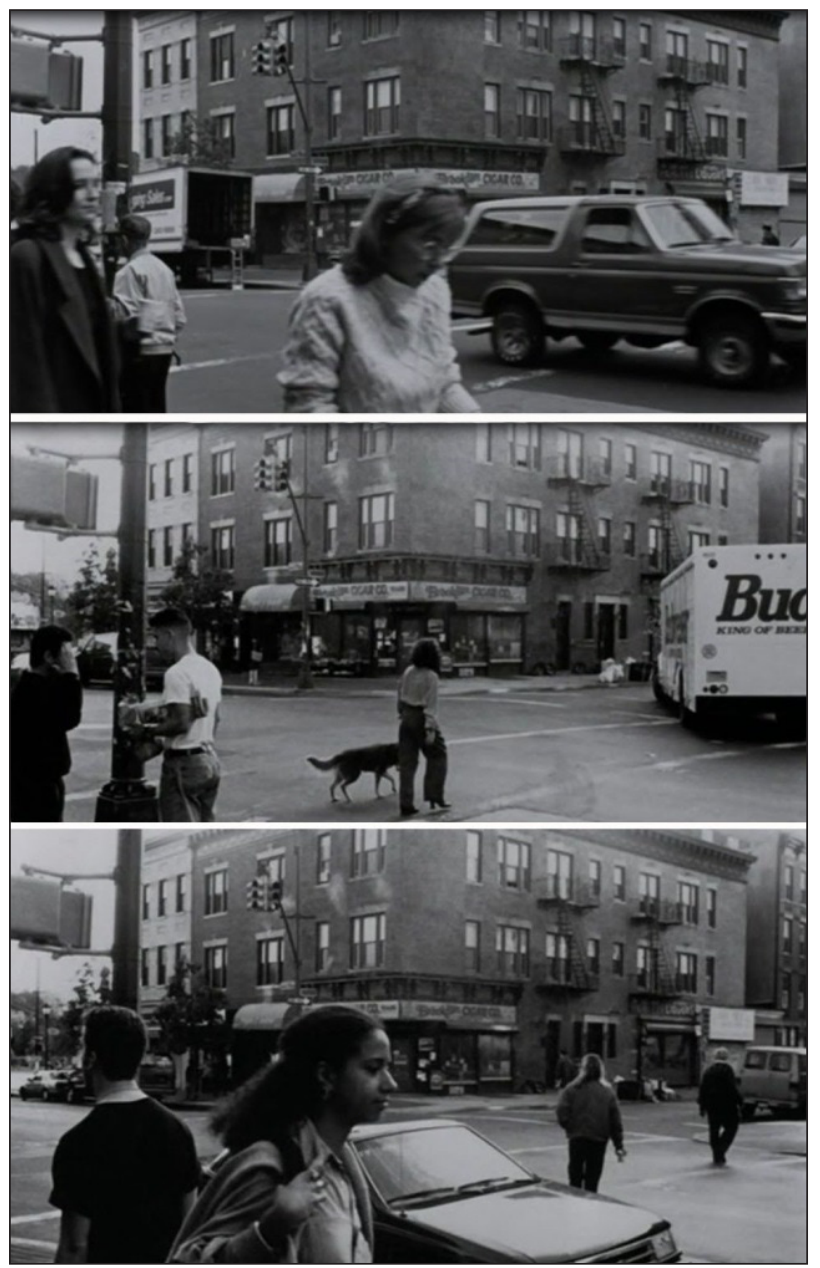

Figura 8 - 0 balé da calcada nas fotos de Auggie Wren

Fonte: Fotogramas extráídos do filme Smoke (Wang et al., 1995). Cortesia de MIRAMAX, LLC.

traz consigo uma sucessão permanente de olhos. Essa ordem compõe-se de movimento e mudança, e, embora se trate de vida, não de arte, podemos chamá-la, na fantasia, de forma artística da cidade e compará-la à dança - não a uma dança mecânica, com os figurantes erguendo a perna ao mesmo tempo, rodopiando em sincronia, curvando-se juntos, mas a um balé complexo, em que cada indivíduo e os grupos têm todos papeis distintos que, por milagre, se reforçam mutuamente e compõem um todo ordenado. 0 balé da boa calçada urbana nunca se repete em outro lugar, e em qualquer lugar está sempre repleto de novas improvisações. (Jacobs, 2003, p. 52)

As imagens congeladas em preto e branco de Auggie são então transformadas na cena corrente, em cores, que mostra os transeuntes enquanto Auggie fotografa na calçada.

Em outra cena externa do filme, na qual ocorre o "quase" atropelamento de Paul Benjamin, é interessante notar, ao fundo, o movimento: passam adultos a pé, idosos, crianças correndo e brincando, pessoas sentadas em bancos etc. 0 balé da calçada é mostrado em tempo real e acompanhado pelo movimento de carros nas ruas.

A diversidade dos usos e do comércio, condição necessária, segundo Jacobs (2003, p. 37), para assegurar o intenso movimento na calçada, aparece nas duas cenas externas descritas anteriormente. Essa diversidade é reforçada pela estrutura do tecido urbano e uso do solo, descritos nas análises sobre o Park Slope e o Brooklyn Heights.

\section{O convívio no espaço urbano e a construção das relações sociais}

No ambiente público de convívio do bairro, existe uma expectativa do comportamento coletivo a ser atendida. Segundo Pierre Mayol, portar-se publicamente exige do indivíduo a avaliação entre as perdas e os ganhos resultantes do ajuste de seu comportamento a um padrão aceitável. Entre os benefícios, está ser aceito por seus pares como uma pessoa da coletividade (Certeau et al., 2000, p. 46).

Em Smoke, os diretores não economizam ao mostrar a variedade de tipos urbanos e situações nas quais se envolvem. Isso é percebido em transeuntes e nos frequentadores das cenas de restaurante, bar e tabacaria, nas quais se nota a combinação de características físicas, de vestimenta e de comportamento. A diversidade demonstra que o limite do "aceitável", termo utilizado por Mayol, é construído cultural e coletivamente, e torna-se muito democrático em uma cidade como Nova Iorque. Por conta disso, as personagens, com seus erros, acertos e dilemas morais, são o principal material explorado por Auster em suas estórias.

Segundo Jacobs (2003, p. 60), a postura de portar-se coletivamente é aprendida no próprio contato diário com a cidade. Por isso a autora insiste na convivência das pessoas nas ruas. Segundo ela, um usuário do espaço público poderá intervir em alguma situação de risco, mesmo não tendo relação direta com o evento, por um sentido de responsabilidade e confiança desenvolvido a partir da vida na cidade. Jacobs narra 
em seu livro situações em que pessoas que estão de passagem podem intervir decisivamente em casos de emergência. Esse tipo de fenômeno é explorado por Auster para costurar as estórias e as personagens, como no exemplo em que Rashid é impelido a salvar Paul Benjamin de ser atropelado.

No entanto, a autora aponta para a complexa rede de relações sociais que se estabelece ao longo do tempo nas vizinhanças e que constituem, do mesmo modo que o espaço físico, um patrimônio importante do bairro. Estas relações sociais que vão se aprofundando permitem suporte mútuo, concedem identidade ao sujeito e representam oportunidades econômicas. Ao apontar para o tempo necessário para a construção dessas redes de relações, a autora conclui pela fragilidade delas nos casos em que ocorre o desmantelamento do bairro. Mayol, por sua vez, chama a atenção para depoimentos de pessoas idosas, as quais vão perdendo os vínculos e sentindo a transformação do bairro à medida que sua rede de relacionamentos vai se extinguindo.

Auster coloca em seu roteiro a importância das relações sociais para a construção de um suporte mútuo: se, por um lado, Rashid consegue um emprego na tabacaria de Auggie por intermédio de Paul, por outro causa grande preocupação ao comerciante, por quase arruinar sua credibilidade.

\section{A prática do bairro e a conveniência}

Segundo Mayol (Certeau et al., 2000, p. 41), o limite de um bairro é subjetivo e está relacionado ao espaço urbano que o usuário é capaz de percorrer a pé. 0 autor afirma que a noção de bairro é moldada pelas apropriações do espaço e pela capacidade de prolongar e separar, indissociavelmente, o espaço privado e público. 0 espaço privado é sempre o ponto de partida da experiência do bairro, local a partir do qual o usuário aventura-se no espaço urbano e para onde ele retorna.

Ao incluir o estudo do bairro em pesquisa, Mayol justifica que:

[...] o bairro é, quase por definição, um domínio do ambiente social, pois ele constitui para o usuário uma parcela conhecida do espaço urbano na qual, positiva ou negativamente, ele se sente reconhecido. Pode-se portanto apreender o bairro como esta porção do espaço público em geral (anônimo, de todo mundo) em que se insinua pouco a pouco um espaço privado particularizado pelo fato do uso quase cotidiano desse espaço. A fixidez do habitat dos usuários, o costume recíproco do fato da vizinhança, os processos de reconhecimento - de identificação - que se estabelecem graças à proximidade, graças à coexistência concreta em um mesmo território urbano, todos esses elementos práticos se nos oferecem como imensos campos de exploração em vista de compreender um pouco melhor esta grande desconhecida que é a vida cotidiana. (Certeau et al., 2000, p. 40).

A vivência cotidiana dos espaços urbanos estabelece vínculos afetivos e hábitos, o que tornará familiar, para o indivíduo, certos espaços públicos. Dessa maneira, o termo hábito estende-se no sentido de habitar a cidade, isto é, a capacidade de se sentir confortável e se reconhecer nos espaços de uso comum da cidade. Nesse sentido, a percepção do espaço do bairro é única para cada usuário, pois depende basicamente da relação que este estabelece com o lugar e, assim como as relações sociais, é diretamente implicada pela passagem do tempo.

O que se vê do uso do bairro, a partir do filme de Auster? Em primeiro lugar, pode-se situar um ponto fixo: o apartamento de Paul ou a própria tabacaria, entendida como espaço habitado. Em uma segunda esfera, podemos ampliar certa familiaridade a lugares que se frequenta habitualmente, como restaurantes e cafés. São locais onde se chama a atendente pelo nome (como na cena em que Paul Benjamin leva Rashid para tomar uma limonada) ou que se encontra um conhecido por acaso (no bar, em comemoração ao aniversário de Rashid). Em outra cena, Paul e Auggie almoçam em uma delicatéssen, que também funciona como mercearia, um local conhecido de ambos, "[...] com bons sanduíches de pastrami e fotos dos antigos times dos Dodgers [...]" (Auster, 2009, p. 23). Nessas cenas está implícito que os espaços para refeição e encontro são lugares próximos a moradias, utilizados cotidianamente e onde é possível reconhecer as demais pessoas.

Em uma terceira esfera de espaços apropriáveis, podemos incluir os espaços públicos, presentes nas cenas da calçada e do parque. 


\section{"Reabitar a rua"}

Além dos espaços internos apresentados no filme, é interessante estender a leitura da apropriação do espaço do bairro para os espaços livres externos. 0 filme fornece, em diversos momentos, algumas oportunidades para essa discussão.

Um bom exemplo é a cena em que os funcionários varrem a calçada em frente à tabacaria. Trata-se de um ato comum nos estabelecimentos comerciais de rua. 0 próprio ato de varrer a calçada expande o cuidado para o espaço público. No filme, essa tarefa, na qual até os gestos são reproduzidos mecanicamente, é ensinada a Rashid como um hábito. Enquanto isso, Auggie dorme sentado em uma cadeira colocada na calçada. As três figuras juntas estão desempenhando cenas íntimas em público, agindo como se estivessem dentro do espaço doméstico (Figura 9).

Na cena do "quase" atropelamento de Paul, passa-se rapidamente por um restaurante com mesas externas, dispostas na calçada. Xavier Monteys (2012) em Rehabitar, no capítulo que aborda a rua, utiliza a imagem de uma pintura chamada Cena in casa de Levi, de Veronese, para salientar o uso do espaço público para uma atividade íntima, como almoçar. 0 ato de comer na calçada está normalmente presente em cafés e bares na cidade. Essa prática contém uma dupla relação: quem está sentado desfruta do movimento e o passante identifica locais de animação. Utilizar o espaço externo para desempenhar certos usos é um hábito antigo que coincide com as formas de morar mais primordiais, onde o limite entre o espaço externo e o espaço interno não era tão claro e, portanto, restritivo. Sobretudo, o uso do espaço público está fortemente presente no comércio.

\section{A Promenade: o Brooklyn Bridge Park}

Em determinada cena do filme, Auggie e Ruby conversam enquanto caminham pelo Brooklyn Bridge Park. A cena externa mostra o uso intenso da orla do Brooklyn junto a esse espaço público, e uma busca em mapas e fotos revela a proliferação desses piers e promenades ao longo da margem do East River. Além dos atributos da paisagem (o rio, a vista para a Ilha de Manhattan, os arranha-céus e a ponte do Brooklyn) e as instalações físicas do parque (calçadão, bancos, vegetação), os usuários são os grandes protagonistas dessa cena. Em 50 segundos de tomada aberta, passam

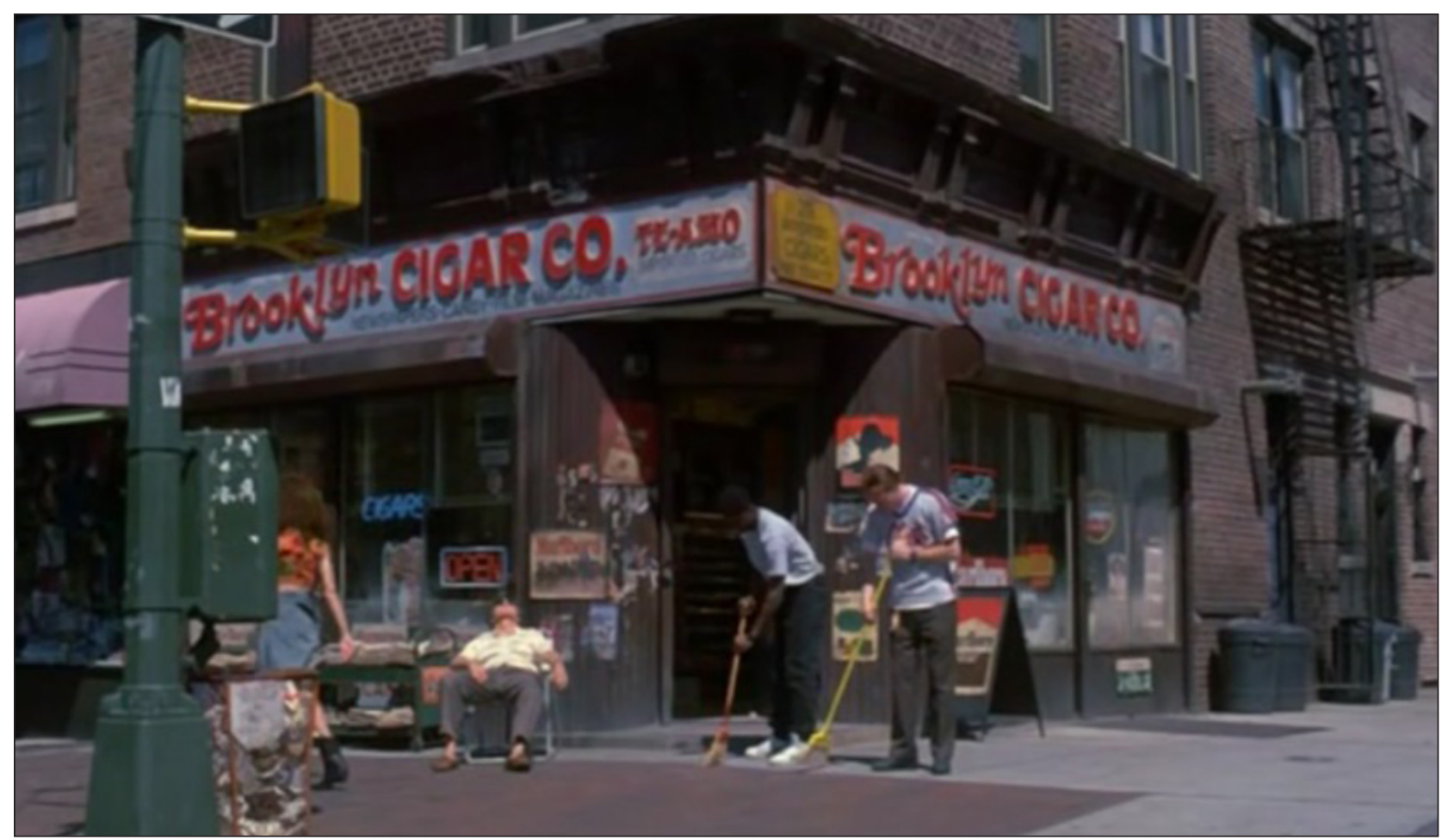

Figura 9 - Varrer e dormir na calçada

Fonte: Fotograma extraído do filme Smoke (Wang et al., 1995). Cortesia de MIRAMAX, LLC.

urbe. Revista Brasileira de Gestão Urbana (Brazilian Journal of Urban Management), 2017 jan./abr., 9(1), 35-51 
pedestres, corredores, skatistas, patinadores, ciclistas e cadeirantes (Figura 10).

Jacobs (2003) tem um capítulo de seu livro dedicado à vida nos parques e praças. Além de procurar identificar elementos de atração nos parques e defender o estímulo visual e de usos, a autora salienta que o parque, como os demais elementos urbanos, irá somar-se a outros fatores para determinar a vida ou morte dos espaços urbanos. Sendo o entorno um ambiente qualificado e adensado, o parque torna-se naturalmente um promotor da intensidade e exuberância urbanas. Nesse sentido, o Brooklyn Bridge Park é beneficiado e, ao mesmo tempo, contribui para o Brooklyn Heights e a cidade de Nova Iorque em termos de vitalidade urbana.

\section{O conjunto residencial moderno}

No filme, ao relatar a estória de Natal, Auggie descreve sua visita a um conjunto habitacional moderno. O local que ele visita é identificado como um conjunto em Boerum Hill, distante apenas quatro quadras da Atlantic Avenue, a localização da tabacaria. O conjunto é central e ocupa apenas duas quadras. Circundado pelo tecido urbano da cidade tradicional, destaca-se negativamente justamente por constituir uma exceção à morfologia do entorno. A impressão perspicaz sobre o conjunto atribuída à personagem revela a postura crítica de Auster, morador do Brooklyn, com relação à cidade.

A descrição do conjunto evidencia as diferenças entre dois modelos de ocupação: a cidade tradicional e o urbanismo moderno (Figura 11). 0 comerciante comenta que demorou em encontrar o prédio que estava procurando, pois tudo lhe pareceu igual. A colocação de Auggie Wren especifica a falta de referências urbanas naquele trecho de cidade onde os prédios são idênticos. A falta de referências visuais soma-se à pouca delimitação dos espaços livres, uma vez que os edifícios estão soltos em meio a áreas abertas, constituindo uma relação invertida de cheio-e-vazio com o tecido urbano presente no entorno e diluindo a delimitação da rua.

\section{A violência urbana}

No filme de Auster, o cuidado de uma personagem com a outra se dá após o estabelecimento de vínculos, por meio de relações e fatos que se encaixam de modo pretensamente aleatório, mas muito bem articulados e orquestrados pelo roteiro. 0 filme mostra o passante,

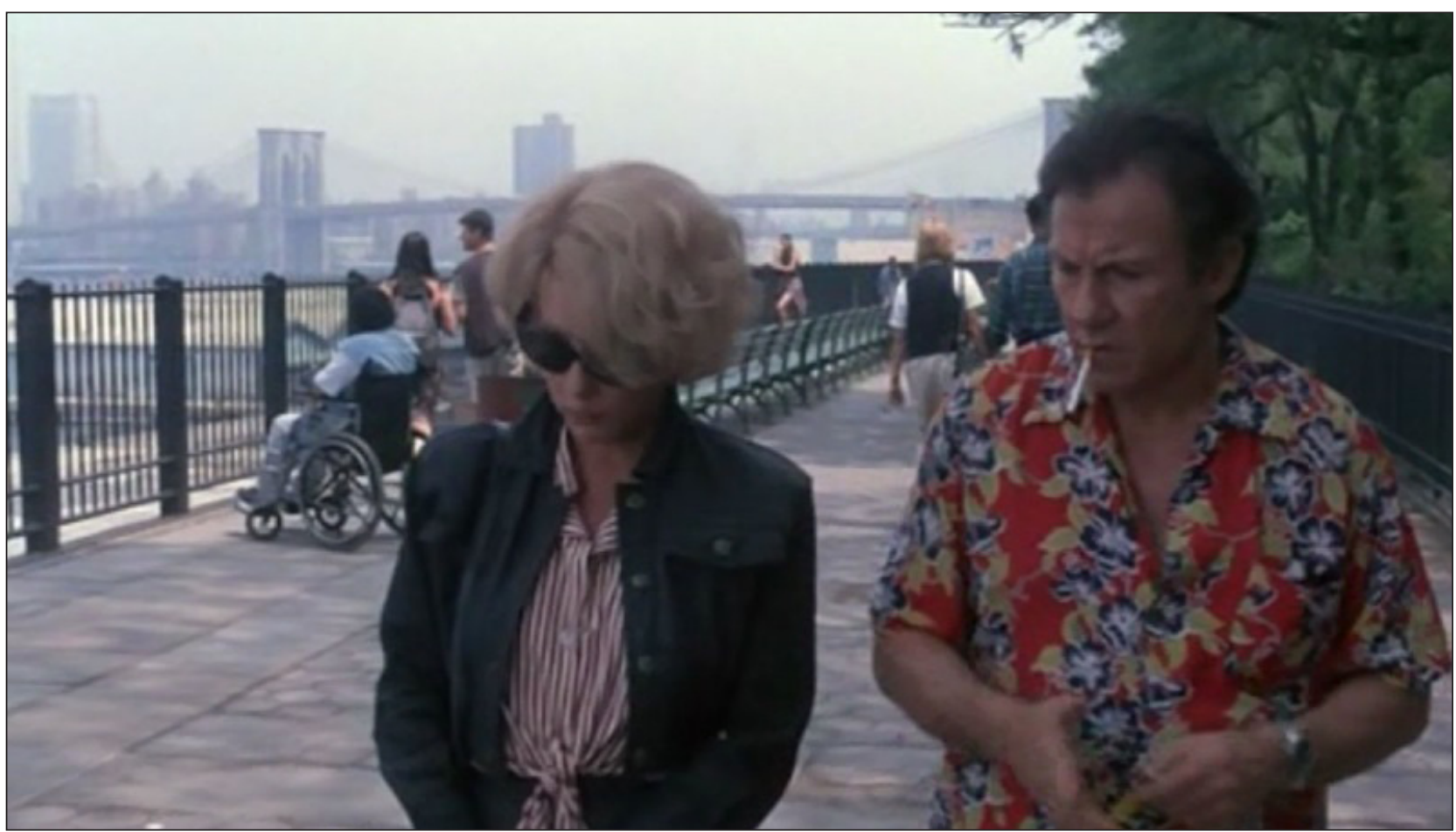

Figura 10 - 0 parque urbano

Fonte: Fotograma extraído do filme Smoke (Wang et al., 1995). Cortesia de MIRAMAX, LLC. 


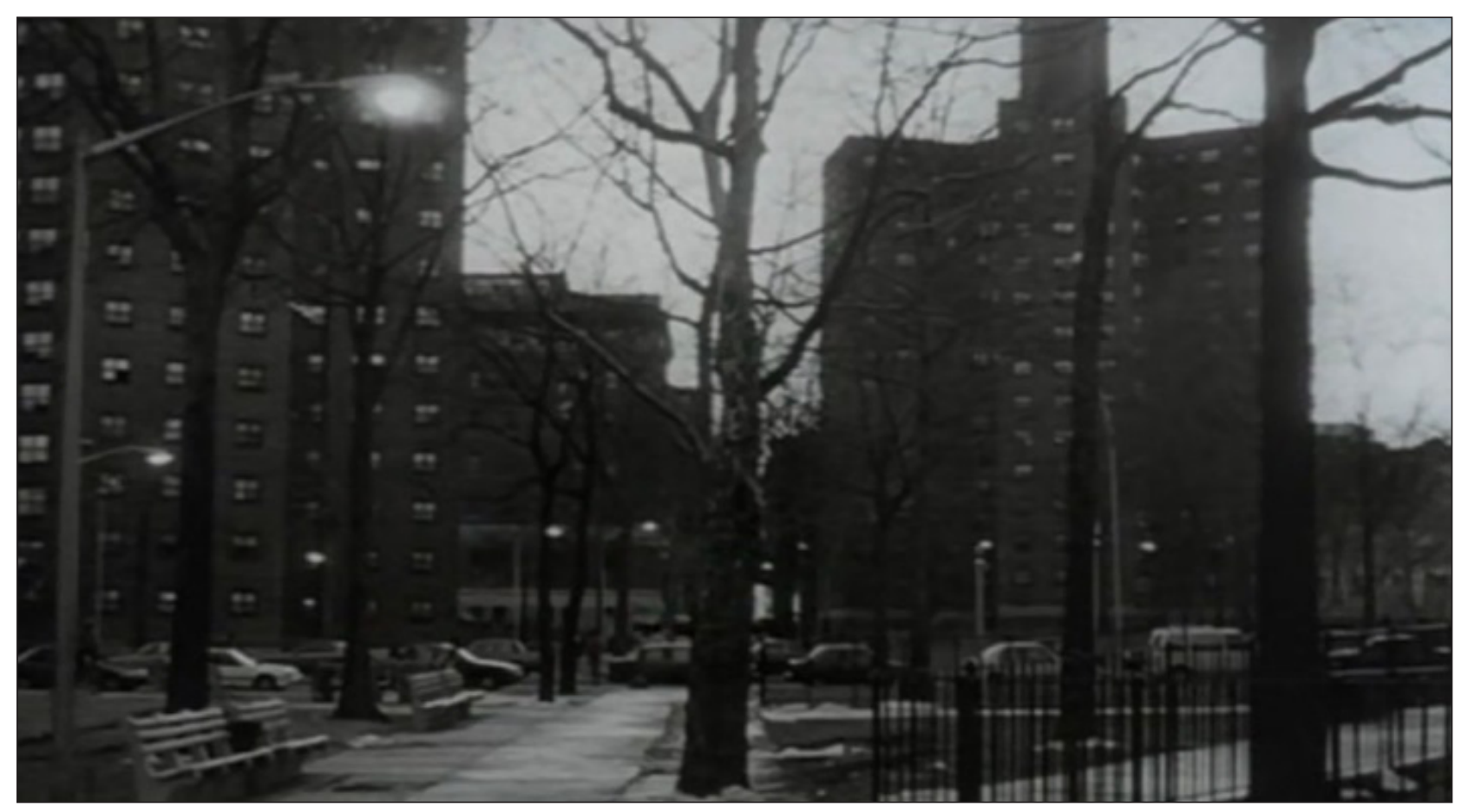

Figura 11 - 0 conjunto residencial moderno

Fonte: Fotograma extraído do filme Smoke (Wang et al., 1995). Cortesia de MIRAMAX, LLC.

o habitante anônimo, mas também personagens que vão se abrindo e se relacionando, enquanto são tocados por eventos trágicos da vida urbana.

Ao mesmo tempo que constrói relações humanas de amparo mútuo, o filme de Auster revela o lado violento da vida metropolitana, ao conter episódios como assaltos, mortes, perseguições, espancamento etc. Foi assim que Paul Benjamin teve sua casa invadida e sofreu agressão física, que sua mulher faleceu de bala perdida em um assalto e que Rashid teve que se esconder. Essas ocorrências, no entanto, não pretendem necessariamente reforçar a imagem da violência, pois não são tratadas como uma finalidade em si. Seu papel é enfatizar a falta de sentido da vida contemporânea isoladamente e, ao mesmo tempo, construir uma repercussão polifônica desses eventos para mostrar que fatos aleatórios vinculam-se entre si para compor o quadro geral da estória, discutindo questões como interferência, possibilidade e acaso.

\section{A estrutura dialógica do filme}

Para finalizar, após um ensaio que aborda, primeiramente, as questões de espaço e relações sociais urbanas, é conveniente mencionar a complexa construção do texto e do filme. Em determinada cena, o autor aciona Mikhail Bakhtin ${ }^{6}$, cuja obra fornece algumas possibilidades de interpretação para a obra de Auster.

Questão fundamental que permeia o filme, bem como o resto da obra de Auster, é a relação autor-personagem. Ao teorizar sobre essa questão, Bakhtin discute sobre a alteridade do autor, sobre o tipo de personagem e seu destino. 0 que vemos em Auster é o excesso de alteridade e exemplos de situações nas quais uma personagem assume o lugar de outra, ou assume o lugar do autor, ou o próprio autor se coloca como personagem. $\mathrm{O}$ fato de o autor estar exteriorizado e representado na forma de uma personagem (Paul Benjamin) materializa sua "extraposição" com relação às personagens e, neste caso, com relação a si próprio, evidenciando o "eu" na situação de "outro". Esses conceitos estão presentes na interpretação de Lemos sobre Bakhtin, a partir do texto original do autor russo, "O autor e o personagem na atividade estética”. Segundo Lemos (2011, p. 40):

\footnotetext{
${ }^{6}$ Paul Benjamin conta a Rashid a estória verídica na qual Bakhtin "fuma" o próprio livro por falta de papel para enrolar o tabaco.
} 
[...] a relação autor-personagem se dá como acontecimento estético a partir do momento em que o autor assume esse excedente de visão como uma posição extraposta ou exotópica que lhe permite construir a personagem como totalidade.

0 fato de o autor estar representado em cena ${ }^{7}$, por meio de Paul Benjamin, traz nova luz para a leitura de diversos diálogos do filme, ao expor conversas diretas entre o "autor" e suas personagens. As situações que se colocam são as mais diversas, por exemplo:

- Personagem Rashid que se apresenta a Cyrus como Paul Benjamin (personagem transforma-se no autor);

- Personagem Rashid que intercede em um diálogo com April Lee, assumindo falas de Paul Benjamin (personagem "compõe" a fala do "autor");

- Benjamin (autor) pergunta se Rashid ficará bem e este, de certo modo, devolve a pergunta ao primeiro ("the world is my oyster", em referência a Auster);

- Benjamin dirige e conduz diretamente as falas entre Auggie e Rashid, nas cenas em que ambos devem se conciliar após Rashid ter alagado as caixas de charuto (o autor impõe-se às personagens que não querem se falar, e elas fazem exatamente o oposto do que o autor solicita);

- Cyrus e Benjamin, "pai-real" e "pai-autor" de Rashid, com o mesmo braço machucado, fumam charuto juntos.

A relação autor-personagem encontra um paralelo na relação pai-filho. A referência à paternidade percorre todas as estórias do filme. Paul Benjamin perdeu o filho que não nasceu; Rashid busca o pai; Auggie é informado sobre sua possível filha Felicity; esta, por sua vez, acaba de fazer um aborto. A referência às questões de paternidade incluiria o próprio tema do Natal, entendido como uma estória fantástica de nascimento e paternidade sem vinculação de crença, uma vez que Auster é judeu.

\footnotetext{
${ }^{7}$ Este recurso não é novo na obra de Auster. Em "A Trilogia de Nova Iorque" (1986), o personagem Quinn, ao se disfarçar, assume o nome de Auster.
}

Do mesmo modo que explora a alteridade do autor e das personagens, a atitude de Auster é dialógica ao pulverizar a autoria do texto, atribuindo-a ao contato com outros. Essa característica está presente ao creditar a estória de Natal a Auggie Wren.

Sendo Auggie Wren o pseudônimo de uma pessoa que supostamente existe, o caráter ficcional da estória pende para a realidade e é imbuído de uma falsa veracidade que aumenta seu caráter fantástico. Apesar de Auster confirmar a existência do vendedor de cigarros, não é possível certificar a origem da estória de Natal, o que transforma o sorriso de Auggie, ao final do livro e filme, no próprio riso de Auster e deixa a nós, leitores, na condição de dúvida.

A celebração da troca e a importância desta para a construção do discurso dialógico aparecem nas entrevistas de Auster à BFI Film Forever e à Annette Insdorf, na introdução aos roteiros de Cortina de Fumaça e de Sem Fôlego (Auster, [1995]), nas quais o autor afirma ter feito o roteiro "para" Wayne Wang. Conforme o pensamento bakhtiniano, o destinatário da mensagem, e não apenas o sujeito, participa ativamente na construção do diálogo (Brait, 2011, p. 20). Essa participação deve-se, em parte, à formação coletiva da linguagem, mas também deve-se à percepção, pelo emissor, do rebatimento de si no outro, ou, ainda, como queremos ressaltar, ao provocar a moldagem do discurso do emissor. Essa moldagem carrega-se daquilo que o autor presume que seja seu interlocutor. Auster é claro ao afirmar que escreveu um roteiro que seria confortável para Wang filmar, ou seja, redigiu o roteiro a partir do que considera característico em Wang como diretor.

Além de ter submetido o roteiro a Wang, Auster distribui, de certo modo, a autoria do texto com sua esposa e com o produtor Robert Altman, o qual, segundo o escritor, sugeriu a introdução de uma personagem crucial na trama de estórias ${ }^{8}$.

Ao mesmo tempo que celebra a autoria da estória diluída pelo contato com outros, percebendo a si mesmo inserido no fenômeno dialógico, Auster imprime tamanha condição de autoria em sua obra (condição verificada a partir da relação entre Smoke e seus demais livros, como "A Trilogia de Nova Iorque"), que se torna inegável compreender a fala de Auster como um indicativo da coerência entre a postura

\footnotetext{
${ }^{8}$ Auster mantém em sigilo a identidade da personagem sugerida por Altman.
} 
cotidiana do escritor e sua literatura, ou seja, a vida real e a ficção.

Se Bakhtin fundamenta a estrutura dialógica explorada por Auster no roteiro, também fornece subsídios para compreensão acerca da sobreposição de múltiplas personagens e estórias. Segundo Peuter (1998), o dialogismo literário teorizado por Bakhtin rejeita a propensão ocidental em direção à síntese e à ordem, e privilegia a coarticulação de forças. Cada personagem é construída a partir de uma multiplicidade de vozes que se rebatem coletivamente, evitando o tom uníssono e considerando a simultaneidade de opostos. Conforme a autora, "a alternativa dialógica dá status igual às forças de síntese e dispersão, ordem e desordem". É possível perceber, no roteiro de Auster, o rebatimento dessas teorias por meio da ressonância entre as estórias, nas quais os eventos ou discursos, vividos por todos os personagens, colaboram para uma construção coletiva e multifocal desta architectonic novel, que tende a dissipar-se e construir-se em um constante fluxo de relações e de fatos.

Entretanto, mais do que a sobreposição de fragmentos e multiplicidade de pontos de vista, o termo "ressonância" poderia ser aplicado em Smoke, pois as estórias tratam de temas recorrentes, com a possibilidade de identificação de diversos paralelos dentro do filme, entre os quais convém mencionar:

- As cinco estórias contadas abordam o tema da paternidade/maternidade; pode-se incluir também a estória contada por Paul Benjamin sobre o alpinista;

- As cinco estórias têm episódios paralelos de mentira (nomes, identidades), roubos e violência urbana;

- As estórias contêm elementos trágicos imprevisíveis, que mudam no presente ou no passado a trajetória das personagens;

- As estórias contêm conflitos éticos com limites duvidosos, desconstruindo valores estabelecidos e relativizando-os.

Por fim, cabe observar a categorização que Bakhtin faz das personagens com relação ao destino. Esse assunto está presente e é discutido no filme pelas próprias personagens. Enquanto Cyrus lamenta sua condição inexorável e credita a Deus (no caso, Auster) seu papel trágico, Rashid tem grande impetuosidade e atitude desafiadora com relação a Paul Benjamin, tornando-se o próprio andarilho criador do seu destino. A personagem Auggie, por sua vez, aponta para o paradoxo de não se saber o devir. Entretanto, o leitor, cônscio da arquitetura de Paul Auster, tem elementos para notar a sobreposição da realidade parcial percebida pela personagem com a ficção cuidadosamente construída pelo autor. Daí também a confusão que se apresenta no filme entre os termos "paradoxo" e "paraíso", apontando para a fruição que vem da complexidade presente em calculado "acaso". Convém considerar que a literatura e o cinema de Auster enquanto ficção abordam e discutem fenômenos sociais e urbanos, explorando a construção complexa e polifônica da vida na metrópole, ou seja, explora o modo como as relações pessoais e espaciais afetam cotidianamente a vida das pessoas, dotando essas relações de uma feição estética.

\section{Referências}

Auster, P. (2009). Conto de Natal de Auggie Wren. São Paulo: Companhia das Letras.

Auster, P. ([1995]). Cortina de Fumaça/Sem Fôlego. Rio de Janeiro: Editora Best Seller.

BFI Film Forever. (2013). Paul Auster on Smoke [Vídeo]. Recuperado de https://www.youtube.com/ watch?v=5q-N1tEHi4s

Brait, B. (2011). As vozes bakhtinianas e o diálogo inconcluso. In D. L. Barros, \& J. L. Fiorin (Orgs.), Dialogismo, polifonia, intertextualidade: em torno de Bakhtin (p. 11-27). São Paulo: Edusp.

Certeau, M., Giard, L., \& Mayol, P. (2000). A invenção do cotidiano 2: morar, cozinhar. Petrópolis: Vozes.

Google. (2015). Google Maps. Recuperado em 16 de agosto de 2015, de https://www.google.com.br/ maps/@-23.549928,-46.5981689,15z

Jacobs, J. (2003). Morte e vida de grandes cidades. São Paulo: Martins Fontes.

Lemos, C. T. G. (2011). A função e o destino da palavra alheia. In D. L. Barros, \& J. L. Fiorin (Orgs.), Dialogismo, polifonia, intertextualidade: em torno de Bakhtin (p. 3743). São Paulo: Edusp. 
Monteys, X. (2012). Rehabitar em nueve episodios. Barcelona: Editorial Lampreave.

Peuter, J. (1998). The dialogics of narrative identity. In M. M. Bell, \& M. Gardiner (Orgs.), Bakhtin and the Human Sciences (p. 30-47). London: Sage Publications.
Wang, W., \& Auster, P. (Diretores) \& Auster, P. (Roteirista). (1995). Smoke (Trad. Cortina de Fumaça). [Filme]. EUA, Alemanha, Japão: Miramax Films, NDF, Eurospace.

Recebido: Out. 22, 2015

Aprovado: Jan. 04, 2016 